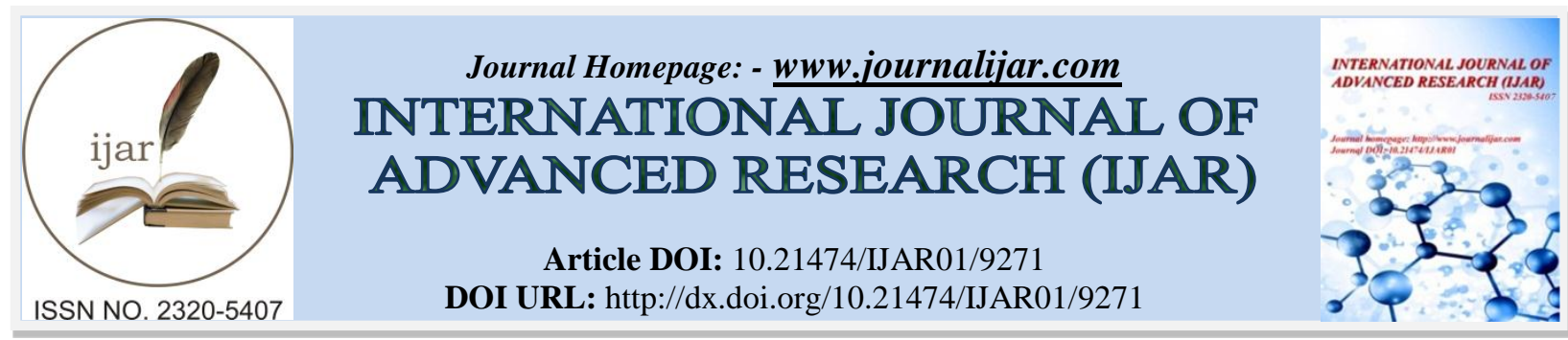

RESEARCH ARTICLE

\title{
PROJECTION OF INTENSITY DURATION FREQUENCY CURVES IN A CONTEXT OF CLIMATE CHANGE IN THE CITY OF LOME (WEST AFRICA).
}

\author{
Gbafa Kodjvi Senanou ${ }^{1}$, Afio Ayarema ${ }^{1}$, Samah Ouro-Djobo E. ${ }^{2}$, Tiem Sonnou ${ }^{1}$ and Kokou Kouami ${ }^{3}$. \\ 1. Ecole Nationale Supérieure d'Ingénieurs, Université de Lomé. \\ 2. Centre de Formation pour l'Entretien Routier CERFER Togo. \\ 3. Faculté Des Sciences, Université de Lomé.
}

\section{Manuscript Info}

\section{Manuscript History}

Received: 12 April 2019

Final Accepted: 14 May 2019

Published: June 2019

Key words:-

Climate change, Intensity duration

frequency curves, urban hydrology.

\begin{abstract}
Urban hydrology models are tools for dimensioning and diagnosing drainage systems for runoff from impervious surfaces. These models undergo an irreversible upheaval in the face of climate changes that impact rainfall intensities. This study aims to analyze the effect of climate change on rainfall intensities in the city of Lomé through the elaboration of Intensity Time Frequency (IDF) curves for future climate for three (03) normals from 2011 to 2100.

The analysis of rainfall intensities in a changing climate was carried out using the IDF_CC version 1.2 tool on 50 years pluviographers data of the Lomé airport synoptic station. The efficiency of retention basins in a changing climate was determined by comparing the threshold intensity with the theoretical intensities.

The results show a large difference between the reference curves and the existing curves obtained from the same historical data. The results also indicate a significant difference in rainfall intensities between current climate and the three future periods considered, regardless of the scenario used and the return period. These results, however, demonstrate a downward trend in intensities for RCP 2.6 and an upward trend in rainfall intensities using the RCP 8.5 scenario which is in fact related to very high greenhouse gas emissions. The hydrological response of retention basins in a changing climate gives very low threshold intensities compared to projections. Drainage of urban stormwater in a changing climate is not effective.
\end{abstract}

Copy Right, IJAR, 2019,. All rights reserved.

\section{Introduction:-}

Climate variability has been one of the most shared realities in the world for the last four decades. This climatic variability significantly affects the availability of water resources. West Africa is marked by a significant decrease in annual rainfall of around $20 \%$, which is accompanied by a decrease in the number of rainy events. (Paturel et al., 1998). On the other hand, the rains are increasingly intense and violent (MERF 2016). The short-term rains are indeed the cause of sudden and catastrophic floods. These stormwater floods correspond to localized phenomena in space and time, due to violent rainfall on small hydrological units (Cheik et al., 2007, Wade et al., 2009). The impacts of water invasion are particularly felt in urban areas where the concentration of goods and people is high and the violence of events is accentuated by changes in hydrological processes and flow conditions induced by

Corresponding Author:-Gbafa Kodjvi Senanou.

Address:- Ecole Nationale Supérieure d'Ingénieurs, Université de Lomé. 
urbanization of the environment (Klassou, 2011, Sighomnou et al., 2012). In some regions, the extent of flooding can be further increased, not only because of particularly violent rains, but also because of the consequences of poorly controlled urbanization (lack of infrastructure design, implantation of new neighborhoods in risk areas). ). This is particularly true for cities in developing countries in the tropics (Desbordes \& Bouvier 1990, Elgy et al., 1993).

In Togo and particularly in Lome, construction does not always respect the plan of urbanization. The housing sector is also characterized by a lack of a coherent legislative and regulatory framework for urban planning and construction, a lack of housing policy guidelines and a notorious insufficiency of sanitation facilities (DGH, 2004; Gbafa et al., 2017a). According to Gbafa et al (2017a), the low proportion of retention ponds with gravity drain coupled with the presence of pumping equipment on retention ponds denotes a serious design handicap. Faced with these concerns, many reflections and actions are carried out on the scientific and technical levels. This is why Gbafa et al. (2017b) developed IDF curves for the city of Lomé to provide the scientific elements that can contribute to the reduction of flood risks. Indeed, the IDF curves are the basis of all design studies of stormwater infrastructure management and play a major role in the state of the art of hydrological applications (Willems, 2000; Willems et al., 2012). Increased precipitation results in higher runoff flows that force the hydraulic capacity of urban drainage systems to be exceeded. In a context of climate change, the use of IDF curves developed from past extreme events has a high margin of error that will have to be reduced by integrating the effects of climate change into the model (Mailhot et al., 2006; Sodogas \& Gomado, 2006; CEA, 2015). The methodology for implementing IDF curves assumes that the meteorological data on which they are based remains stationary. This basic hypothesis is refuted against a background of climatic variability given the impacts of these climatic variables on rainfall. It is therefore essential to put in place predictive models that include future climate variability for a better dimensioning of hydraulic systems. It is in this context that the present study which analyzes the effects of the IDF curves in a changing climate on the hydrological response of retention basins in the city of Lome.

\section{Material and methods:-}

\subsection{Study area}

The city of Lomé is located in the extreme south-west corner of Togo (Fig. 1). It extends along the coast of the Gulf of Guinea westwards to the Ghana border. Lome is thus, a border town that currently covers an area of nearly 280 $\mathrm{km}^{2}$ (Adjoussi, 2008). 


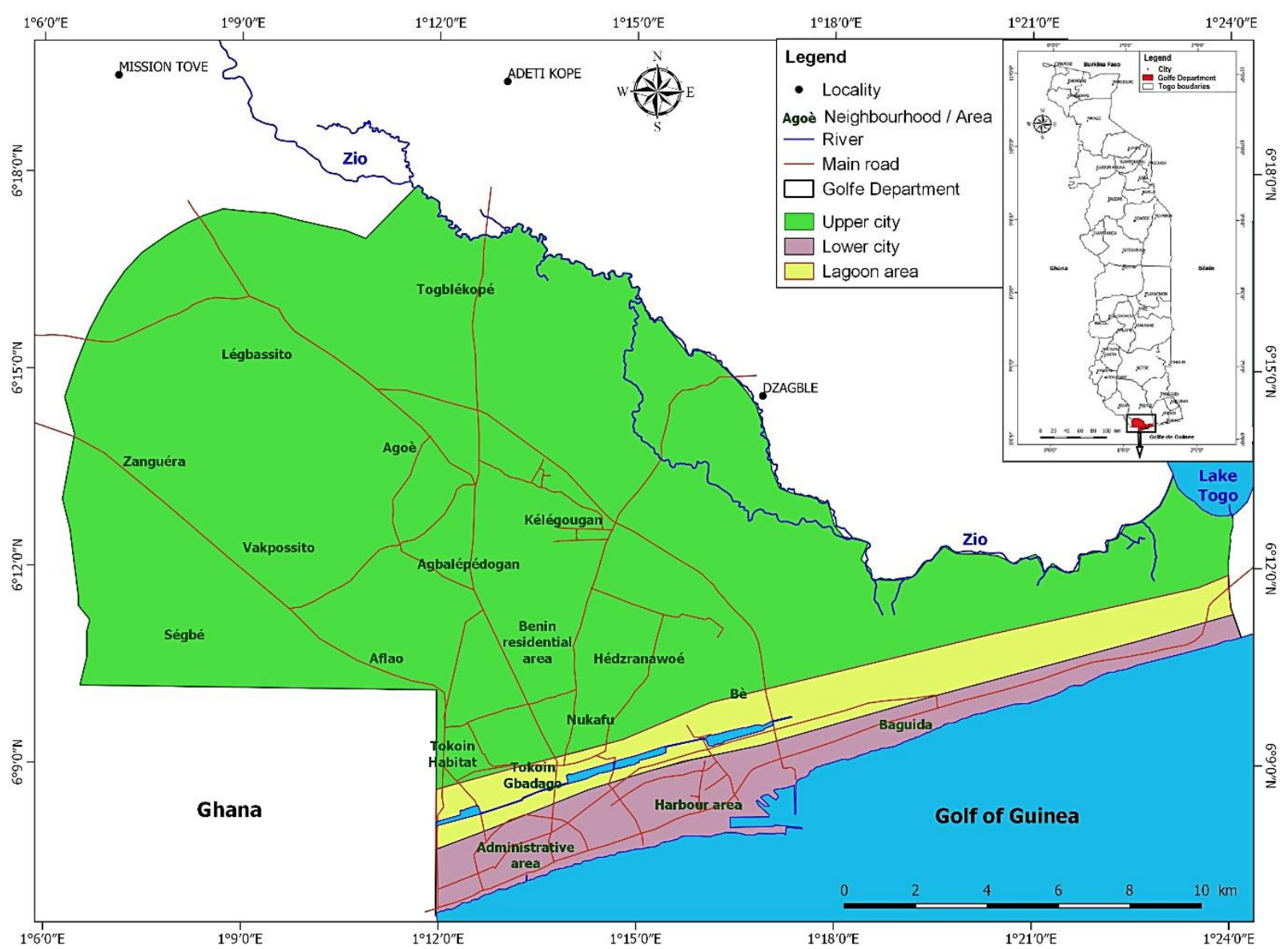

Fig. 1 : Study area

Lomé enjoys a Guinean subequatorial coastal climate characterized by two rainy seasons (March / April to July and September to November), and two dry seasons (in August then between November and February) (Aubréville 1949; Edjame, 1992; Adjoussi, 2000). Lomé is in the part of Togo with the lowest rainfall (800 to $900 \mathrm{~mm}$ of rain per year). The average humidity exceeds $75 \%$. The average monthly minimum values range from $57-58 \%$ during the dry season to $71-73 \%$ during the rainy season (Edjame, 1992; Adjoussi, 2008). The maximum average temperature is $30.7^{\circ} \mathrm{C}$ in the afternoon, and the minimum $23.1^{\circ} \mathrm{C}$ in the morning. From south to north, the city consists of three physiographic zones (Edjame, 1992; Adjoussi, 2008):

- the lower town: located between the sea and the lagoon, it is an ancient flat dune ridge with altitude between 2 and $5.5 \mathrm{~m}$ above sea level. It is the historical heart of Lome.

- The lagoon zone: located about $2.5 \mathrm{~km}$ from the seafront, in places it has a width of about $200 \mathrm{~m}$. The lagoon zone is composed of an equilibrium channel and 3 lakes (West Lake, East Lake, Lake Bè and the $4^{\text {th }}$ lake).

- the upper town: this is the plateau area to the north of the lagoon, rising to a $35 \mathrm{~m}$ altitude. It is bounded in the northeast by the Zio River and in the west by the Ghana border (Adjoussi, 2008).

\subsection{Collection of rainfall and hydrological data}

Most of the data used for this study consists of two series of recordings of the pluviographers of the Lomé airport synoptic station. The first series concerns the data on maximum intensities systematically stripped (Binguitcha-Fare, 2003) over a period of 33 years (1965-1997). The second series includes the daily rainfall highs obtained from the General Directorate of National Meteorology (DGMN) for a period of over 50 years (1961 to 2010) for the same station. The raw data in Microsoft Excel format has been calculated in the IDF_CC version 1.2 tool and the results 
exported as Microsoft Excel data are in turn supported in the R studio software for statistical tests and graph plotting.

\subsection{Determination of rainfall intensities in a changing climate}

The analysis of rainfall intensities in a changing climate was carried out using the IDF_CC version 1.2 tool. This tool takes into account the impacts of climate change on stormwater management. It allows to generate the IDF curves corresponding to a given region for any future period up to 2100 .

\subsubsection{Choice of climate model and scenarios}

The IDF_CC version 1.2 tool offers a range of climate models consisting of 22 GCM models selected from the 41 models developed by different research centers (IPCC, 2007). The tool assigns a skill score to each of the 22 models so that the more the score tends to zero, the better the tool (Sirastav et al., 2015). The most suitable climate model for the city of Lomé is the "bcc-csm1-1-m" developed by China.

\subsubsection{Establishment of IDF curves in a changing climate}

The climate change IDF curves were generated for the historical data (reference curve) and for the three RCPs (RCP2.6, RCP4.5 and RCP8.5). Three future periods are used for the generation of the IDF curves: the period between 2011 and 2040, the period from 2041 to 2070 and the period from 2070 to 2100. The curves of the IDF_CC model are in the form of equation 1.

$I(t)=A(C+t)^{\wedge} B$

The differences between future and historical climate have also been estimated. For each scenario, average values of rainfall intensities were calculated, making it possible to evaluate the relative variation of intense rainfall between future and historical climate for the different durations and return periods considered. Boxplots were made for this purpose and variance analyses (ANOVA) were performed. This comparison also considered the IDF curves derived from the work of Gbafa et al. (2017b). Only rainfall intensities of durations 15, 20 , 30 and 60 minutes will be compared because the concentration time of watersheds in the city of Lome is between 13 and 59 minutes (Gbafa et al., 2017b). It should also be noted that these three scenarios represent the most commonly used scenarios and the figures for each of the profiles express the change in radiative forcing associated with GHG emission concentrations (Mailhot et al., 2014) (RCP2.6 Mitigation Scenario) that lead to a very low forcing level; RCP4.5 Stabilization Scenario; RCP8.5 Very High Greenhouse Gas Emissions Scenario).

\subsubsection{Hydrological response of retention basins in a changing climate}

For the analysis of the efficiency of the sanitation facilities, only the fitted out retention ponds were studied (Table 1). Unmanaged depressions that function as stormwater storage areas have not been considered. The hydrological data (A surfaces and $\mathrm{C}$ runoff coefficients and concentration time Tc of the basins, $\mathrm{V}$ capacity and infiltration coefficients of basins) are obtained from the Directorate General of Hydraulics (DGH) in Lomé. The flow drained by each basin was calculated and the retention threshold of the basins were estimated.

The flow $\mathrm{Q}\left(\mathrm{m}^{3} / \mathrm{s}\right)$ drained by runoff on a watershed of area $\mathrm{A}$ (in ha), and runoff coefficient $\mathrm{C}$ during a rain of intensity I (in $1 / \mathrm{s}$ ) is expressed by equation 2 of the rational formula. In this equation, $\mu$ represents the conversion coefficient of the units (Musy, 2005).

$$
Q=\mu . C . I . A
$$

The retention threshold of a basin is the intensity of rain which for a duration equal to the concentration time causes the filling of the corresponding retention basin. This relation is represented by equation 3 . By introducing equation 2 into the latter we obtain 4.

$$
V=Q . T C
$$

Volumes discharged by gravity or pumping during a time equal to the concentration time of the contributing watershed are considered in the calculations.

$$
I s=\frac{V}{\mu \cdot C \cdot A \cdot T C}
$$

The comparison of the threshold intensity (Is) and the theoretical intensities per return period will make it possible to know if the retention pond is efficient or not. A pond is efficient when the rain threshold intensity is greater than 
the rain intensity projected. To do this, the threshold intensities are calculated for the durations equal to the concentration time of each basin and compared with those corresponding to the IDF model in a changing climate selected for the city of Lomé for the return period of 2 years. The effect of future time is already taken into account (Benabdesselam \& Hammar, 2009).

Table 1:-Characteristics of the retention ponds (RP) studied (source DGH, 2004)

\begin{tabular}{|c|c|c|c|c|}
\hline $\begin{array}{l}\text { Retention } \\
\text { pond }\end{array}$ & $\begin{array}{l}\text { Runoff } \\
\text { (Ha) }\end{array}$ & $\begin{array}{l}\text { Runoff Coefficient } \\
\text { C }\end{array}$ & $\begin{array}{ll}\begin{array}{l}\text { Concentration } \\
\text { (minute) }\end{array} & \text { Time }\end{array}$ & $\begin{array}{l}\text { Retained } \\
(\mathrm{m} 3)\end{array}$ \\
\hline RP 1.1 & 65 & 0,35 & 34,64 & 4800,00 \\
\hline RP 1.2 & 327 & 0,32 & 38,16 & 45000,00 \\
\hline RP 2.1 & 141 & 0,35 & 56,00 & 29107,00 \\
\hline RP 2.1' & 142 & 0,35 & 56,00 & 20865,00 \\
\hline RP 2.2 & 72 & 0,35 & 33,63 & 9564,00 \\
\hline RP 2.4 & 114 & 0,35 & 13,75 & 13724,00 \\
\hline RP 2.5 & 36 & 0,35 & 14,30 & 5600,00 \\
\hline RP 2.7 & 323 & 0,42 & 15,69 & 40000,00 \\
\hline RP 2.7' & 362 & 0,43 & 15,69 & 78000,00 \\
\hline RP 3.1 & 316 & 0,30 & 45,86 & 42000,00 \\
\hline RP 3.3 & 345 & 0,30 & 33,10 & 75000,00 \\
\hline RP 4.1 & 22 & 0,35 & 23,26 & 2400,00 \\
\hline RP 4.2 & 249 & 0,40 & 19,26 & 37000,00 \\
\hline RP 4.4 & 160 & 0,45 & 28,54 & 33000,00 \\
\hline RP 4.6 & 22 & 0,45 & 15,12 & 1800,00 \\
\hline RP 5.3 & 131 & 0,40 & 17,81 & 8000,00 \\
\hline RP 5.4 & 108 & 0,35 & 45,61 & 10000,00 \\
\hline RP 7.7 & 688 & 0,35 & 38,54 & 100000,00 \\
\hline RP 7.8 & 465 & 0,35 & 28,09 & 40000,00 \\
\hline RP 8.1 & 704 & 0,35 & 54,46 & 60000,00 \\
\hline RP 9.1 & 252 & 0,35 & 58,14 & 10000,00 \\
\hline RP 9.2 & 114 & 0,35 & 19,03 & 5000,00 \\
\hline RP 9.7 & 32 & 0,35 & 22,51 & 2000,00 \\
\hline
\end{tabular}

\section{Results:-}

\subsection{IDF curves in a changing climate}

The results obtained show that the three parameters of the IDF curves vary according to the trajectory of the emissions (RCP) and the projection period. In fact, for the first climatological normal (2011-2040), parameter A increases (from 54.10 to 102.10) depending on the return period for the reference curve and those projected with the exception of the return period of 10 years for the RCP 2.6 scenario or there is a slight decrease. The ascending order of parameter A by return period gives AREF <ARCP 4.5 <ARCP 8.5 <ARCP 2.6 (Table 2). Parameter B is negative and takes a constant value $(=-2)$ for the reference curves and increases as function of return period (from -2.205 to 2.000) for all other scenarios except for the period of return of 5 years RCP 2.6 or there is a small decrease. By return period, parameter B is in the following ascending order: B RCP $4.5<\mathrm{B}$ RCP $8.5<\mathrm{B}$ RCP $2.6<\mathrm{B}$ REF. Unlike the first two, parameter $\mathrm{C}$ decreases (from 0.118 to 0.069 ) for the scenarios depending on the return period and increases for the return periods of 2, 5, 10 and 25 years for the reference curve and will keep the latter value for the 50 and 100-year periods (Table 2).

For the same period, the reference curve and the RCP 4.5 curve are almost identical, whereas we observe a significant increase in intensities in the RCP 2.6 and RCP 8.5 scenarios. The latter two results are also similar (Fig. 2). 
Table 2:-IDF curve Parameters for the period 2011 - 2040 and reference period

\begin{tabular}{|c|c|c|c|c|c|c|c|}
\hline \multirow[t]{2}{*}{ Adjustment } & \multirow[t]{2}{*}{ Parameter } & \multicolumn{6}{|c|}{ Return Periods (years) } \\
\hline & & 2 & 5 & 10 & 25 & 50 & 100 \\
\hline \multirow[t]{3}{*}{ Gumbel Distribution } & A & 39.70 & 50.80 & 58.00 & 66.90 & 73.40 & 79.80 \\
\hline & $\mathrm{B}$ & -2.000 & -2.000 & -2.000 & -2.000 & -2.000 & -2.000 \\
\hline & $\mathrm{C}$ & 0.065 & 0.067 & 0.068 & 0.069 & 0.069 & 0.069 \\
\hline \multirow{3}{*}{$\begin{array}{l}\text { RCP } 2.6 \\
\text { Scenario }\end{array}$} & A & 56.10 & 77.30 & $\underline{76.20}$ & 86.60 & 94.30 & 102.10 \\
\hline & B & -2.184 & $\underline{-2.224}$ & -2.064 & -2.032 & -2.014 & -2.000 \\
\hline & $\mathrm{C}$ & 0.113 & $\underline{0.132}$ & 0.084 & 0.077 & 0.072 & 0.069 \\
\hline \multirow{3}{*}{$\begin{array}{l}\text { RCP } 4.5 \\
\text { Scenario }\end{array}$} & A & 54.10 & 61.60 & 66.60 & 73.10 & 77.90 & 82.70 \\
\hline & B & -2.205 & -2.138 & -2.107 & -2.076 & -2.058 & -2.042 \\
\hline & $\mathrm{C}$ & 0.118 & 0.102 & 0.094 & 0.087 & 0.083 & 0.079 \\
\hline \multirow{3}{*}{$\begin{array}{l}\text { RCP } 8.5 \\
\text { Scenario }\end{array}$} & $\mathrm{A}$ & 55.10 & 64.30 & 70.50 & 78.50 & 84.40 & 90.30 \\
\hline & B & -2.194 & -2.120 & -2.087 & -2.056 & -2.038 & -2.023 \\
\hline & $\mathrm{C}$ & 0.115 & 0.098 & 0.090 & 0.082 & 0.078 & 0.075 \\
\hline
\end{tabular}

$\mathrm{A}, \mathrm{B}$ and $\mathrm{C}$ are parameters of equation 1.

Station Lome Aeroport

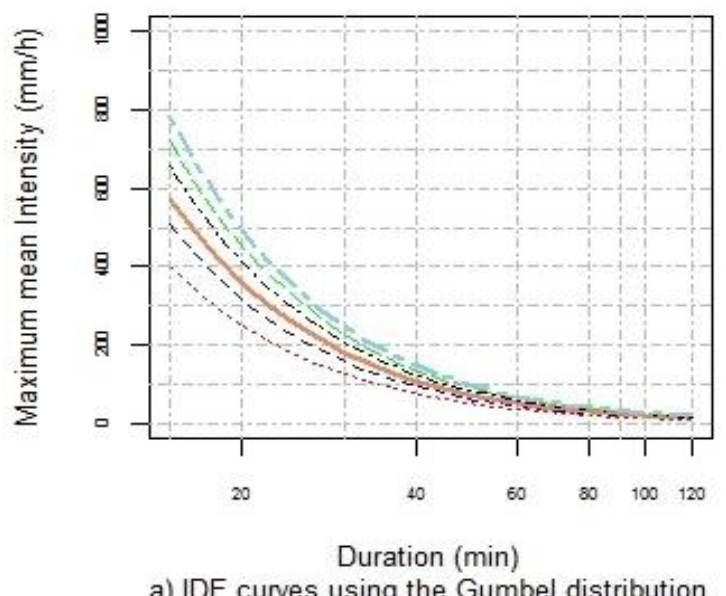

2011-2040

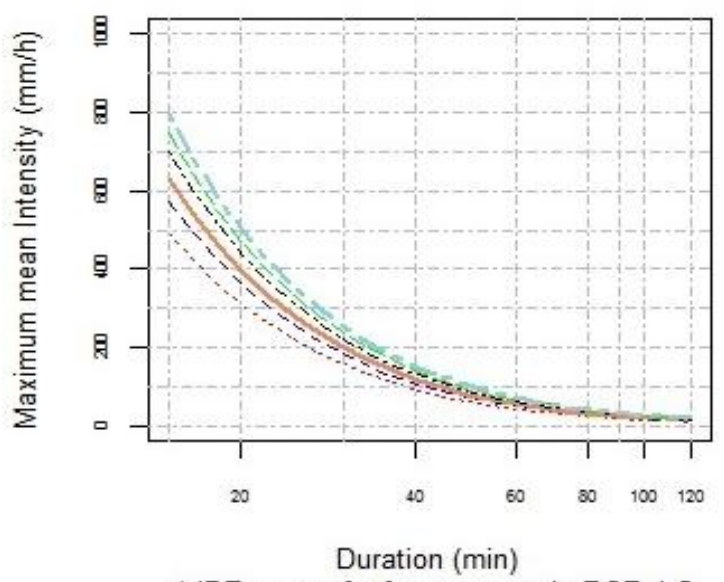

c) IDF curves for future scenario RCP 4.5
2011-2040

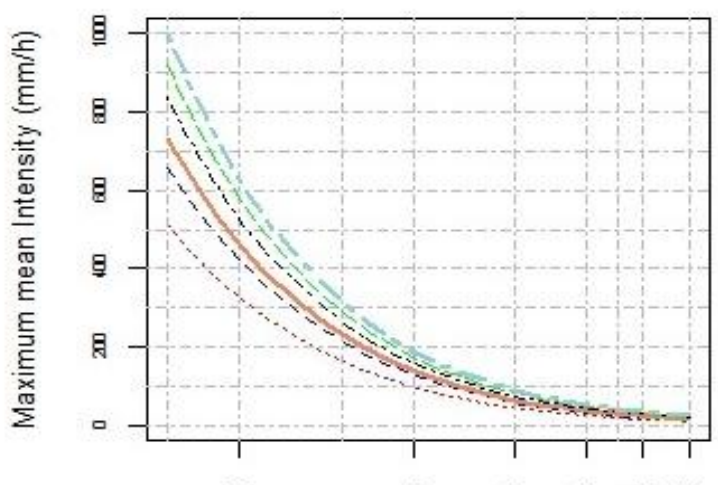

Duration (min)

b) IDF curves for future scenario RCP 2.6

\section{1-2040}

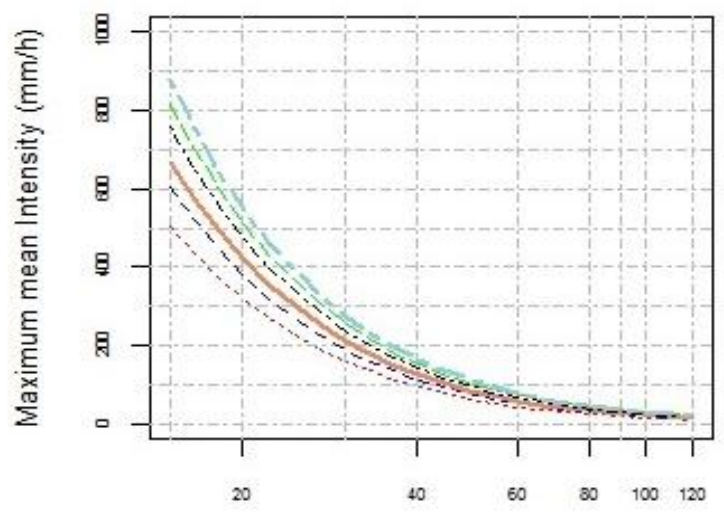

Duration ( $\mathrm{min})$

d) IDF curves for future scenario RCP 8.5

— $\mathrm{T}=2$ years — $\mathrm{T}=5$ years $-\mathrm{T}=10$ years — $\mathrm{T}=25$ years … $\mathrm{T}=50$ years — $\mathrm{T}=100$ years

Fig 2:-IDF Curves in a changing climate from 2011-2040 
For the second normal climatological (2041 - 2070) the same tendencies are observed in the variation of parameters $\mathrm{A}, \mathrm{B}$ and $\mathrm{C}$, moreover there is a decrease in parameters A and C of the RCP 2.6 scenario compared to the first normal as well as the opposite effect for the RCP 4.5 and RCP 8.5 scenarios (Table 3). Parameter B decreased for all three scenarios. The exceptions observed in the evolution of parameters A, B and C during the first climatological normal are repeated exactly for the same RCP 2.6 scenario respectively for the return periods 25 years, 10 years, and 5 years. The intensity increase is remarkable only for the RCP 8.5 scenario while the other two are similar to the reference curve (Fig. 3).

Table 3:-IDF curve Parameters for the period $2041-2070$

\begin{tabular}{|c|c|c|c|c|c|c|c|}
\hline \multirow[t]{2}{*}{ Adjustment } & \multirow[t]{2}{*}{ Parameter } & \multicolumn{6}{|c|}{ Return Periods (years) } \\
\hline & & 2 & 5 & $\mathbf{1 0}$ & 25 & 50 & 100 \\
\hline \multirow[t]{3}{*}{ RCP 2.6 Scenario } & A & 53.50 & 62.00 & 78.40 & 75.10 & 80.60 & 86.20 \\
\hline & B & -2.213 & -2.135 & -2.244 & -2.068 & -2.049 & -2.033 \\
\hline & $\mathrm{C}$ & 0.120 & $\underline{0.101}$ & 0.138 & 0.085 & 0.081 & 0.077 \\
\hline \multirow[t]{3}{*}{ RCP 4.5 Scenario } & A & 56.50 & 64.00 & 69.00 & 75.40 & 80.20 & 85.00 \\
\hline & B & -2.180 & -2.122 & -2.094 & -2.066 & -2.050 & -2.036 \\
\hline & $\mathrm{C}$ & 0.112 & 0.098 & 0.092 & 0.085 & 0.081 & 0.078 \\
\hline \multirow{3}{*}{$\begin{array}{l}\text { RCP } 8.5 \\
\text { Scenario }\end{array}$} & A & 58.40 & 67.80 & 74.20 & 82.50 & 88.30 & 94.40 \\
\hline & B & -2.163 & -2.100 & -2.071 & -2.046 & -2.027 & -2.014 \\
\hline & $\mathrm{C}$ & 0.108 & 0.093 & 0.086 & 0.080 & 0.076 & 0.072 \\
\hline
\end{tabular}

$\mathrm{A}, \mathrm{B}$ and $\mathrm{C}$ are parameters of equation 1.

Station Lome Aeroport

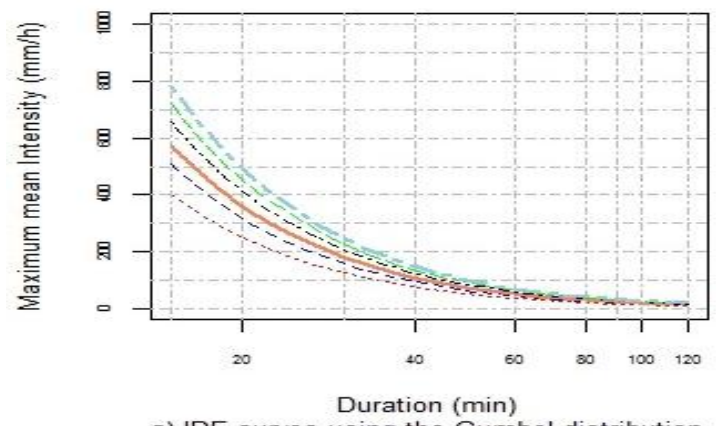

a) IDF curves using the Gumbel distribution

2041-2070

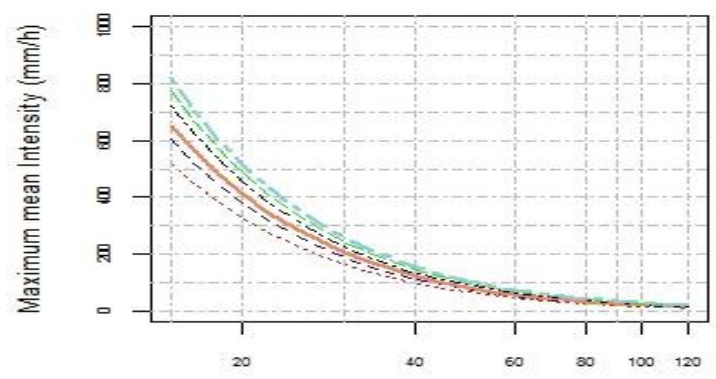

Duration (min)

c) IDF curves for future scenario RCP 4.5

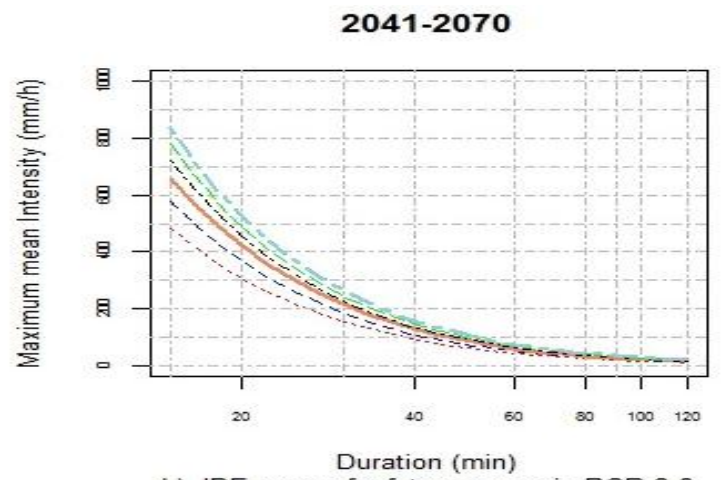

b) IDF curves for future scenario RCP 2.6

2041-2070

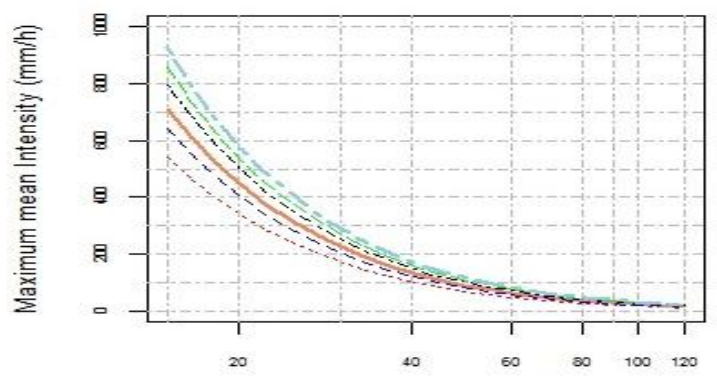

Duration (min)

d) IDF curves for future scenario RCP 8.5

- T $=2$ years $\quad T=5$ years $\quad-T=10$ years

$\mathrm{T}=25$ years

$\mathrm{T}=50$ years

$\mathrm{T}=100$ years

Fig 3:-IDF curves in changing climate for the period 2041-2070 
The third climatic normal (2071-2100) is similar to the first two (Table 4 and Fig.4). The same trends are observed in the variation of parameters A, B and C. In addition, there is a decrease in parameters A and C for the RCP 2.6 scenario compared to the first normal as well as the opposite effect for the RCP 4.5 and RCP 8.5 scenarios. The exceptions observed for the first two climatic normals are observed for the RCP 4.5 scenario only for the return period of 50 years.

Table 4:-IDF curve Parameters for the period 2071 - 2100

\begin{tabular}{|l|l|l|l|l|l|l|l|}
\hline \multirow{2}{*}{ Adjustment } & \multirow{2}{*}{ Parameter } & \multicolumn{6}{l|}{ Return Periods (years) } \\
\cline { 3 - 9 } & $\mathbf{2}$ & $\mathbf{5}$ & $\mathbf{1 0}$ & $\mathbf{2 5}$ & $\mathbf{5 0}$ & $\mathbf{1 0 0}$ \\
\hline \multirow{3}{*}{$\begin{array}{l}\text { RCP 2.6 } \\
\text { Scenario }\end{array}$} & $\mathrm{A}$ & 55.90 & 64.30 & 69.90 & 77.10 & 82.50 & 86.20 \\
\cline { 2 - 9 } & $\mathrm{B}$ & -2.186 & -2.120 & -2.090 & -2.060 & -2.043 & -2.033 \\
\cline { 2 - 8 } & $\mathrm{C}$ & 0.113 & 0.098 & 0.090 & 0.083 & 0.079 & 0.077 \\
\hline $\begin{array}{l}\text { RCP 4.5 } \\
\text { Scenario }\end{array}$ & $\mathrm{A}$ & 59.00 & 67.50 & 73.20 & 80.60 & $\underline{\mathbf{8 6 . 0 0}}$ & 85.00 \\
\cline { 2 - 8 } & $\mathrm{B}$ & -2.158 & -2.102 & -2.075 & -2.049 & $\underline{\mathbf{- 2 . 0 3 3}}$ & -2.036 \\
\cline { 2 - 8 } & $\mathrm{C}$ & 0.107 & 0.093 & 0.087 & 0.081 & $\underline{\mathbf{0 . 0 7 7}}$ & 0.078 \\
\hline $\begin{array}{l}\text { RCP 8.5 } \\
\text { Scenario }\end{array}$ & $\mathrm{A}$ & 67.00 & 79.50 & 87.90 & 98.60 & $\mathbf{1 0 6 . 5 0}$ & 114.40 \\
\cline { 2 - 8 } & $\mathrm{B}$ & -2.105 & -2.052 & -2.029 & -2.006 & -1.993 & -1.982 \\
\cline { 2 - 8 } & $\mathrm{C}$ & 0.094 & 0.082 & 0.076 & 0.071 & 0.067 & 0.065 \\
\hline
\end{tabular}

$\mathrm{A}, \mathrm{B}$ and $\mathrm{C}$ are parameters of equation 1

Station Lome Aeroport

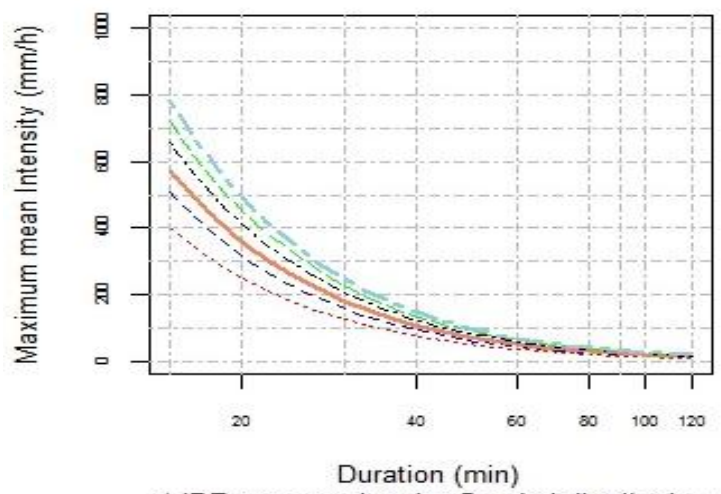

a) IDF curves using the Gumbel distribution

2071-2100

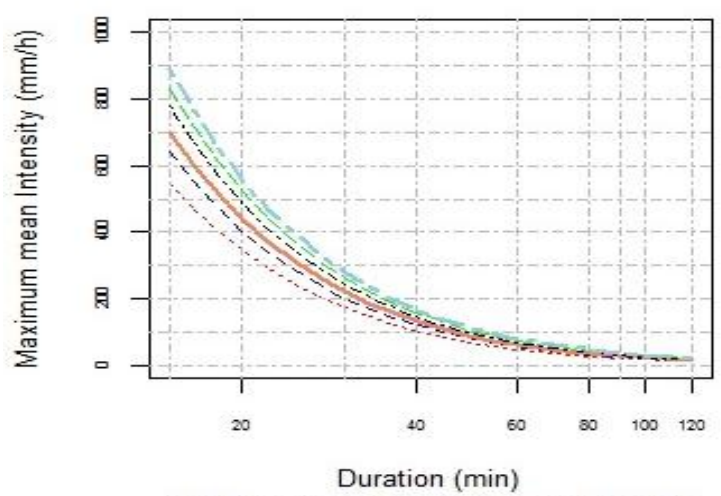

c) IDF curves for future scenario RCP 4.5

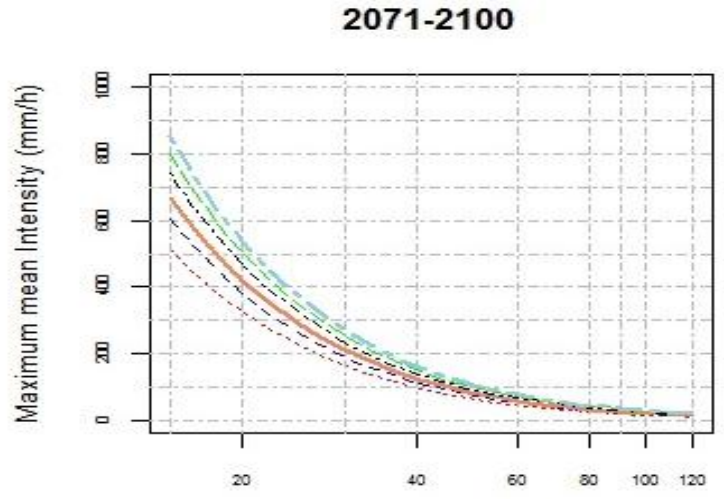

Duration ( $\mathrm{min}$ )

b) IDF curves for future scenario RCP 2.6

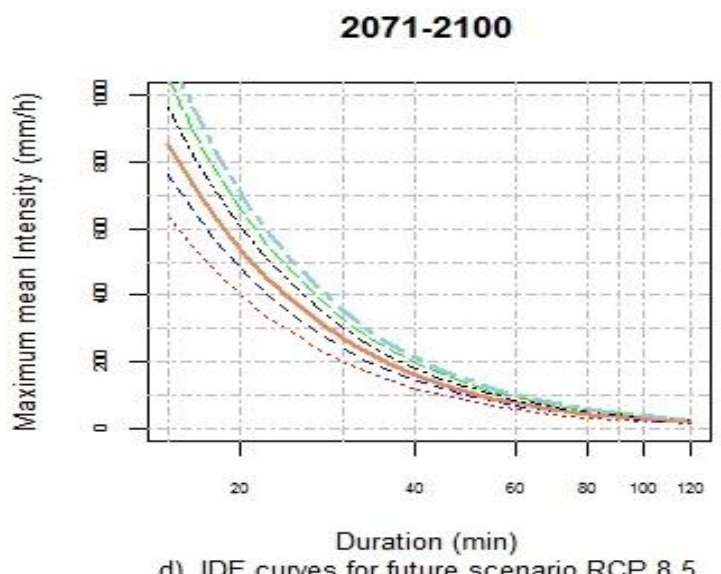

d) IDF curves for future scenario RCP 8.5

$\longrightarrow \mathrm{T}=2$ years $\longrightarrow \mathrm{T}=5$ years $-\mathrm{T}=10$ years $\longrightarrow \mathrm{T}=25$ years $\cdots \mathrm{T}=50$ years $\quad \mathrm{T}=100$ years

Fig 4:-IDF curves in a changing climate for the period 2071-2100 


\subsection{Variability in rainfall intensities in a changing climate}

The results seem to show a clear difference between the intensities of the historical data of the IDF_CC model (box plot J of Figures 5, 6 and 7) and the intensities of Gbafa et al. (2017b) (box plot K of Fig. 5, 6 and 7) while the input data are identical and are those of Binguitcha Fare (2003). However the analysis of variance carried out shows that this difference is not significant $(0.138<p<0.144)$. The difference obtained even if not significant may be related to the nature of the recordings and the method of counting. Indeed it is the paper-based graphic records of the 1960s pluviographs. The mode of stripping is based more on reconstructed hyetograms. The IDF_CC model is developed for data from time-based automatic loggers. Moreover the IDF_CC model considered a single adjustment (Gumbel) while Gbafa et al. (2017b) is based on an optimization of the three usual adjustments per rain duration. It is therefore better to adopt the latter as a reference. For the scenarios; the IDF_CC model integrated daily rainfall high data over a 50-year period. This influenced the results by reducing intensities closer to reality and therefore comparable with those of the reference curves.

Regarding the analysis of rainfall intensities in a future climate, the results seem to show, for the RCP 2.6 scenario, a difference in intensity whatever the return period considered. Indeed, the average rainfall intensity from historical data seems to be higher than the intensity of rainfall in a future climate. Analysis of variance (ANOVA) shows that the difference in intensity is not significant $(\mathrm{P}>0.05)$. This non-significant intensity variation, however, generally indicates a downward trend in intensities ranging from 11.17 to $12.04 \%$ for the RCP 2.6 scenario regardless of return period (Fig. 6).
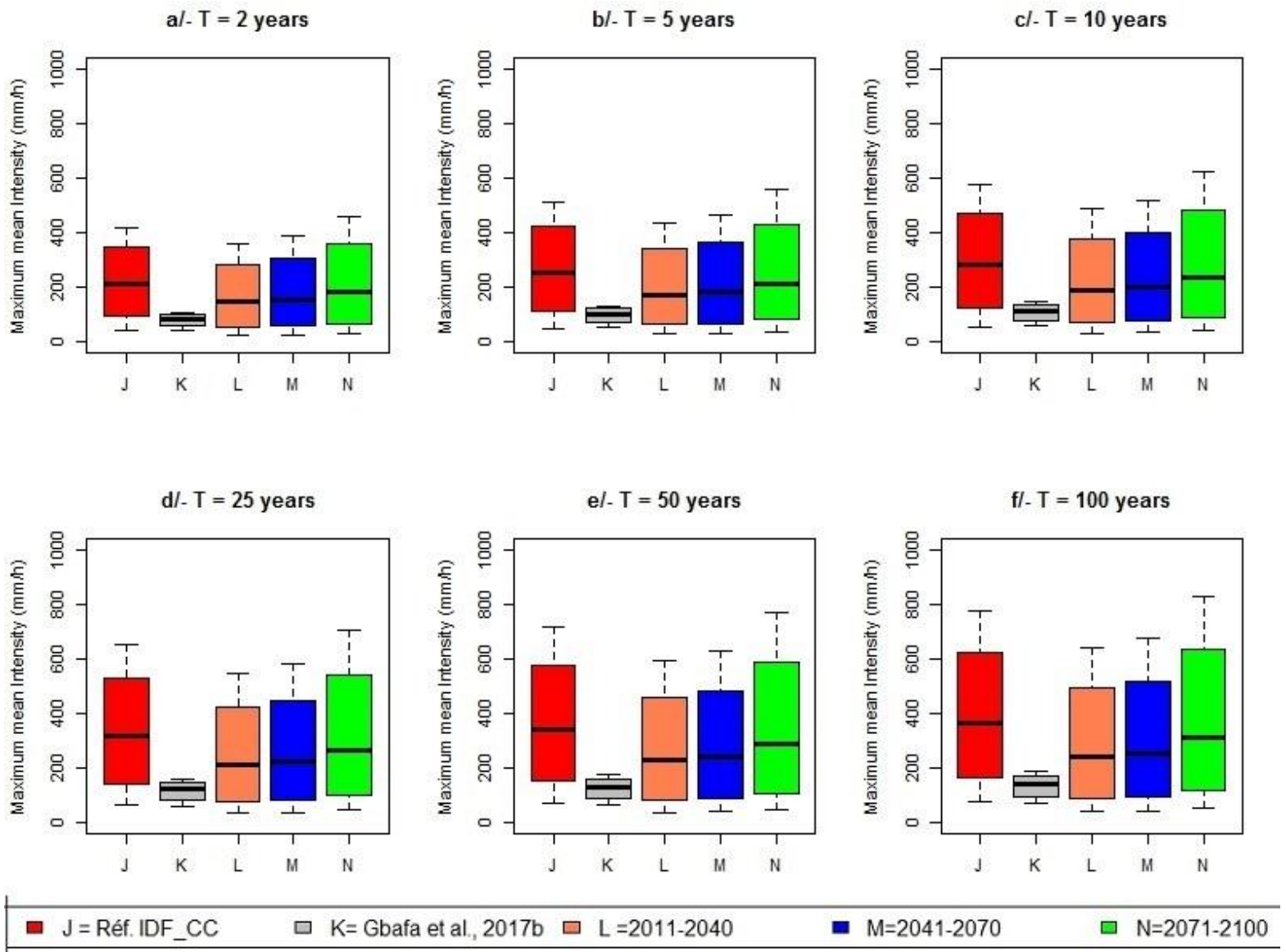

$\mathrm{J}=$ Réf. IDF_CC

$\square \mathrm{K}=$ Gbafa et al., 2017b $\square \mathrm{L}=2011-2040$

- $M=2041-2070$

Fig 5:-Comparison of intensities projected under RCP 2.6

For the RCP 4.5 and RCP 8.5 scenarios, the analysis of the average intensities gives results similar to those obtained for the RCP 2.6 scenario. Indeed bloxplots seem to show that the average intensity of historical data is higher than the others regardless of the period of return. But as in the case of the RCP 2.6 scenario, the analysis of variance indicates a non-significant difference between the rainfall intensities regardless of the return period $(\mathrm{P}>0.05)$. It 
should be noted, however, that for the RCP 4.5 scenario (Fig. 6), the results indicate a tendency towards stability of average rainfall intensities by considering data from Gbafa et al. (2017b) and the three future periods. For the RCP 8.5 scenario (Fig. 7), the results show that there will be an increase (even if it is not significant ( $P>0.05$ ) in average rainfall intensities in the city of Lomé during future periods from 11.87 to $12.25 \%$.

al $-\mathrm{T}=2$ years

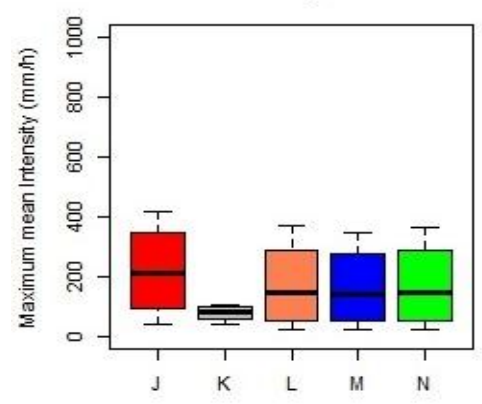

$\mathrm{d} /-\mathrm{T}=25$ years

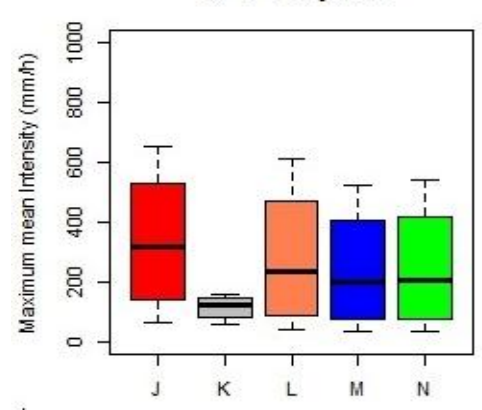

b/ $-\mathrm{T}=5$ years

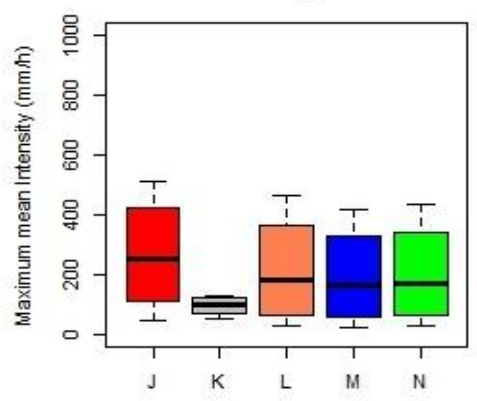

$\mathrm{e} / \mathrm{T}=50$ years

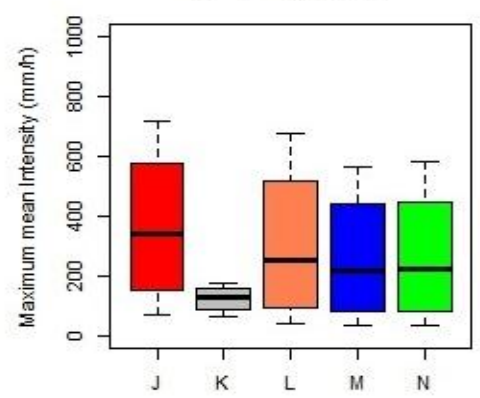

$c /-T=10$ years
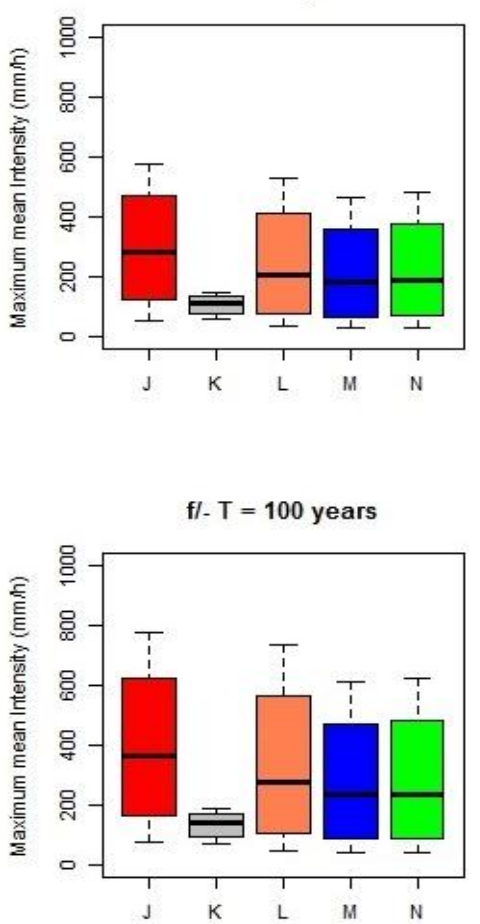

\section{口 J=Réf. IDF_CC $\square \mathrm{K}=$ Gbafa et al., 2017b $\square$ L =2011-2040}

Fig 6:-Comparison of projected intensities under RCP 4.5
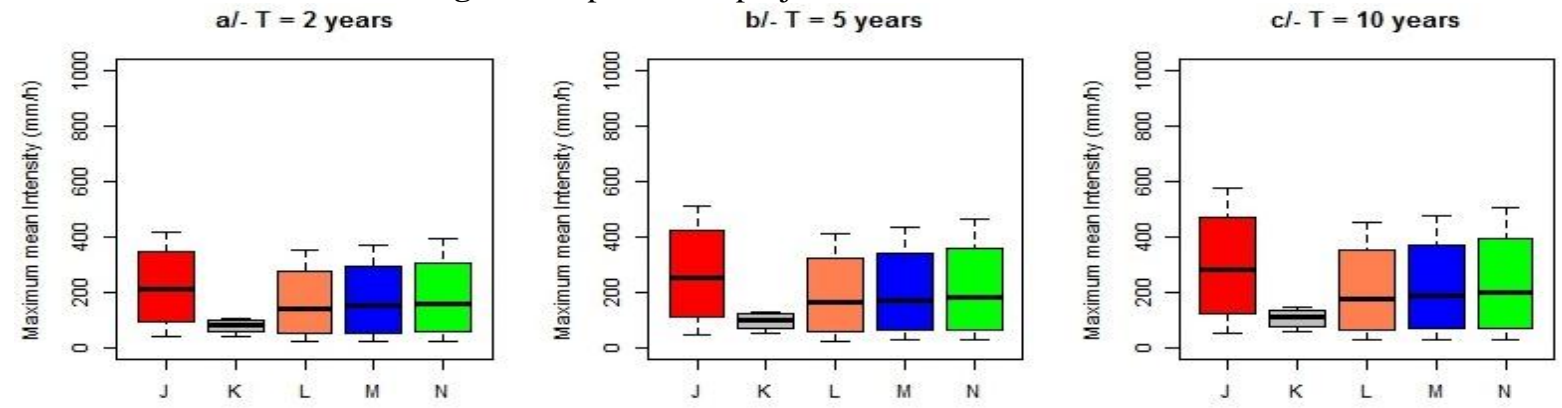

d $/-T=25$ years

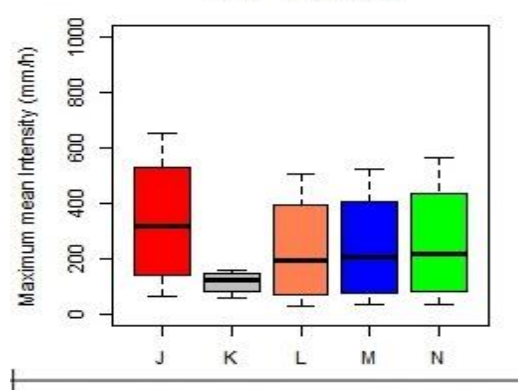

$\mathrm{e} / \mathrm{T}=50$ years

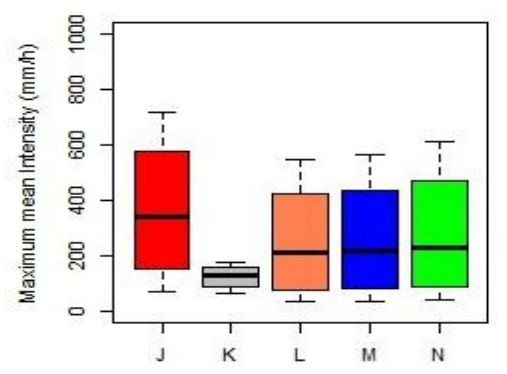

$f /-T=100$ years

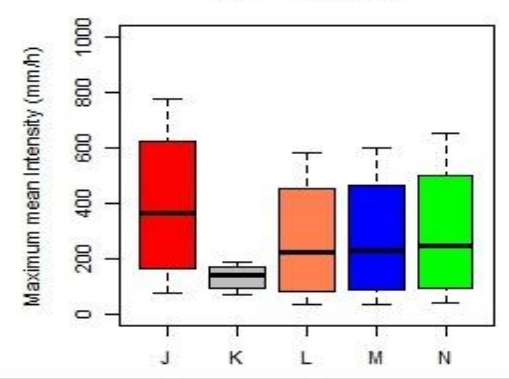

$M=2041-2070$

$\square \quad \mathrm{N}=2071-2100$

Fig 7:-Comparison of projected intensities under RCP 8.5 


\subsection{Hydrological response of retention basins in a changing climate}

Whatever the GHG emission path considered, for the first normal (2011 to 2040) the projected intensities remain very close for each retention basin (standard deviation $<0.22$ ). They range from 0.75 to $9.73 \mathrm{~mm} / \mathrm{h}$ (Fig. 8). The threshold intensities are well below the projected intensities with the exception of RP 2.7. Three other retention ponds (RP 2.1, RP 25 and RP 4.6), although inefficient, have their intensity threshold very close to the projected intensities.

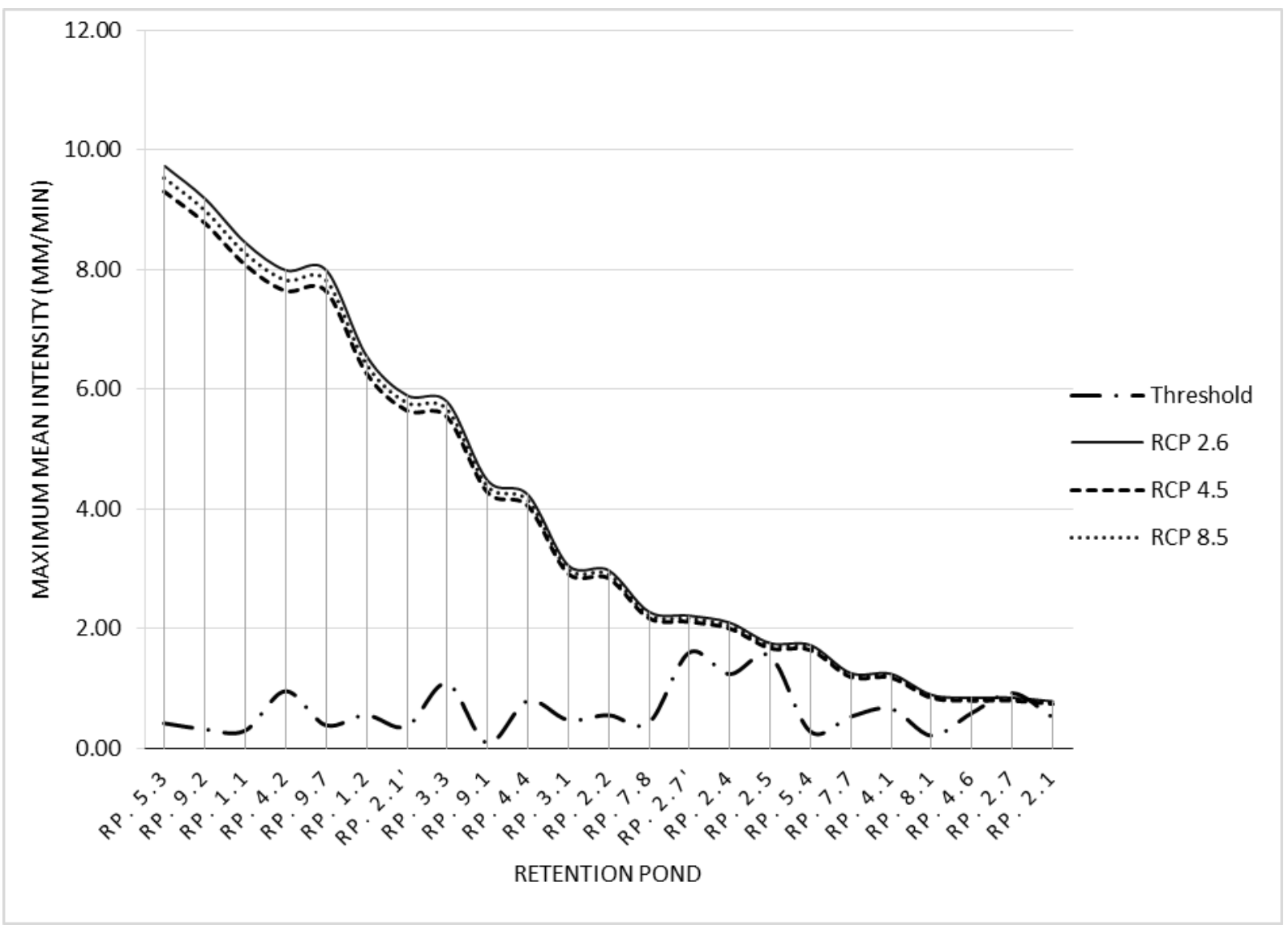

Fig 8:-Thresholds of maximum intensity in a changing climate for the period $2011-2040$

For the second normal, (2041 to 2070) the projected intensities are slightly different according to the GHG concentration trajectory considered. A slight increase in intensities is observed following the RCP 8.5 and a small decrease according to RCP2.6 (Fig. 9). Only the RP 2.7 retention pond remains effective. The three retention ponds (RP 2.1, RP 2.5 and RP 4.6) are still close to the efficiency limit. 


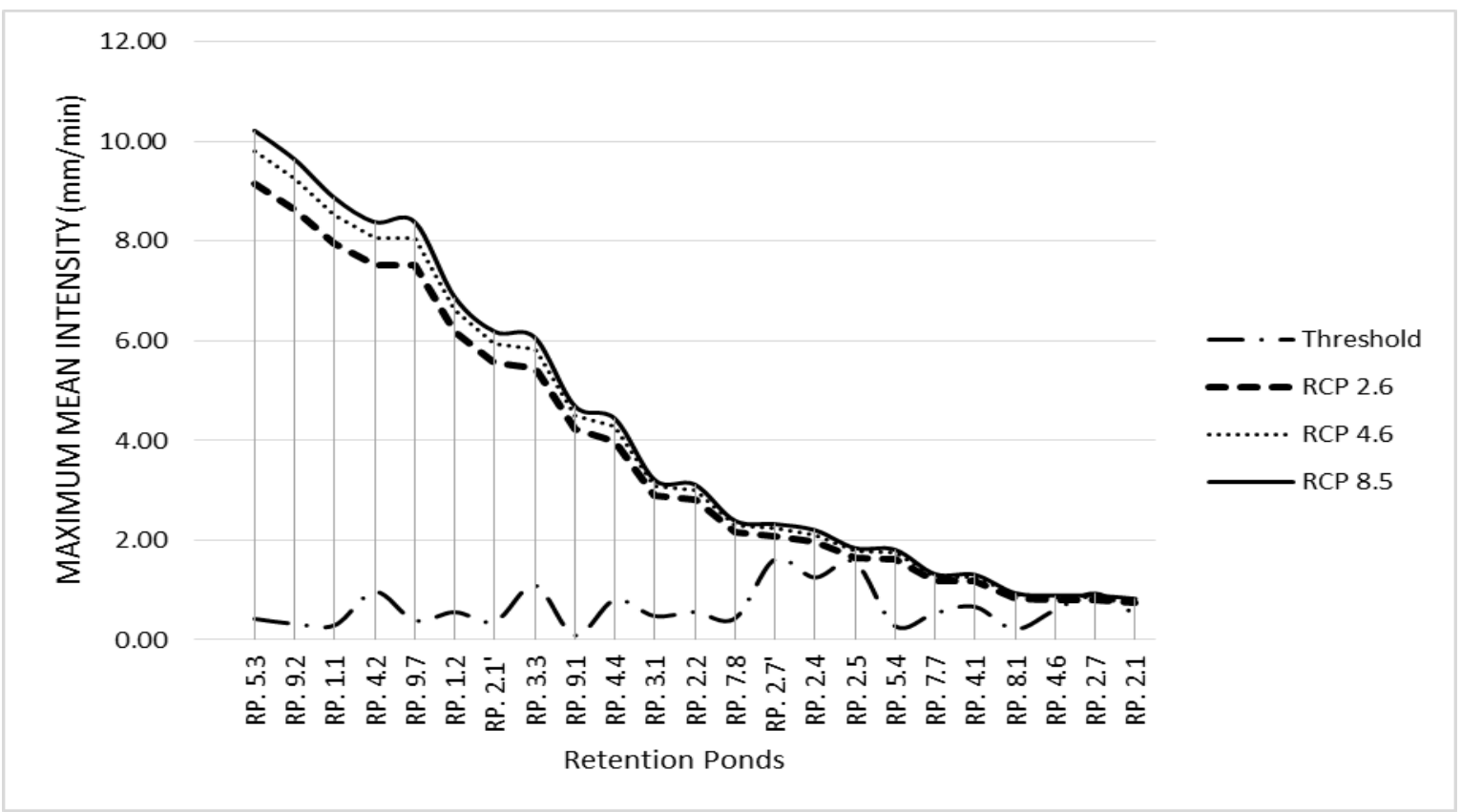

Fig 9:-Thresholds of maximum intensity in a changing climate for the period $2041-2070$

For the third normal, (2041 to 2070) the projected intensities stand out more according to the GHG concentration trajectory considered. There is an increase in intensities according to RCP 8.5 (Fig 10). The RP 2.7 retention pond is effective only for the RCP 4.5 and RCP 2.6 trajectories, and becomes ineffective under RCP 8.5.

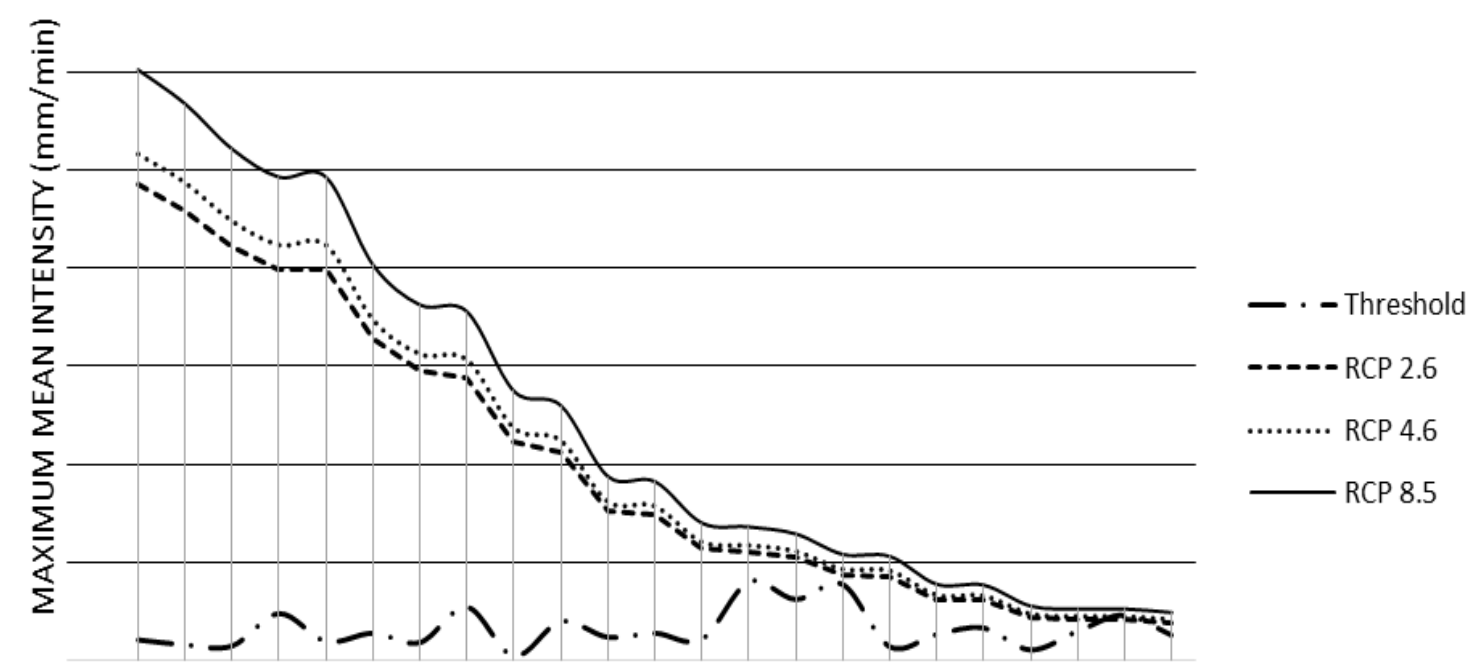

RP. RP. RP. RP. RP. RP. RP. RP. RP. RP. RP. RP. RP. RP. RP. RP. RP. RP. RP. RP. RP. RP. RP. 5.3 9.2 1.1 4.2 9.7 1.2 2.1'3.3 9.1 4.4 3.1 2.2 7.82.7' 2.4 2.5 5.47 .74 .18 .14 .62 .72 .1

\section{RETENTION POND}

Fig 10:-Thresholds of maximum intensity in a changing climate for the period $2071-2100$

\section{Discussion:-}

This study has taken climate change into account in the development of IDF curves in the city of Lomé because the projected increase in intensity and frequency of precipitation (Mailhot et al., 2014) no longer allows the use IDF curves in their basic form the design of these curves is carried out by frequency analysis of past extreme events. In 
this study, the results indicate a significant difference in rainfall intensities between the current climate and the three future periods considered, regardless of the scenario used and the return period. There is, however, a downward trend in rainfall intensities considering the RCP 2.6 scenario on the one hand. Indeed, RCP 2.6 is an attenuation scenario that leads to a very low level of forcing, ie a scenario related to very low greenhouse gas emissions (Stocker, et al,. 2013). On the other hand, there is an upward trend in rainfall intensities using the RCP 8.5 scenario. RCP 8.5 is in fact linked to very high greenhouse gas emissions (Stocker, et al,. 2013). The trend obtained by the RCP 8.5 scenario, even if it is not significant, confirms the work of Stocker, et al,. (2013) and Mailhot et al. (2014) that the impacts of climate change on precipitation are characterized by a probable increase in annual average precipitation, a likely increase in intensities and frequencies of extreme precipitation events. Going in the same direction, Sun et al. (2007) indicate that the global picture points to a situation where wetlands are prone to an overall increase in rainfall (Sun et al., 2007). Recent climate projections, moreover, suggest that during the next decades, extreme rain events will be more frequent (Mailhot et al., 2012, Monette et al., 2012, Lemmen et al., 2008, Mailhot et al. 2007, Zwiers \& Kharin, 1998a, b). These projections are supported in particular by recent analyses confirming that the increase in frequency and intensity of extreme rain events could be linked to the increase in GHGs caused by human activities (Min et al., 2011).

With the impacts of climate change on rainfall and IDF curves, the drainage of urban water in a changing climate is a problem that the city of Lome should face. In the case of rainwater management, the impacts are likely to be significant when the level of service of several item of infrastructure have been established using the rainfall records available at the time of their design based on the hypothesis of stationarity of climate (Shaw \& Walter, 2012; Galloway, 2011; Milly et al., 2008). This hypothesis implies that historical climate data are indicative of the climatic conditions that a structure or an infrastructure will experience throughout its useful life (Huard et al., 2010). However, the useful life of these infrastructure items can exceed half a century, which will lead them to experience a climate quite different from the one in which they were designed (Huard et al., 2010). More frequent extreme rainfall events could increase the risk of flooding and grid surge (Mailhot et al., 2006; PANA. 2008; Olsson et al., 2009; Huard et al., 2010). The analysis of the hydrological responses of retention basins in the city of Lomé in a changing climate indicates threshold intensities in the majority of cases, below the projected intensities. Only the RP 2.7 retention pond functions correctly in a changing climate with a threshold intensity greater than or equal to the projected intensities. The differences are even greater when the concentration times of the watershed considered are less than half an hour (30 minutes) (Wallez, 2010; Gbafa et al., 2017b). This situation implies that the design of new infrastructure, as well as the replacement of existing infrastructure, must be reviewed in the city of Lomé in order to incorporate the modifications of the rainfall regimes in a climate change context even if the trend towards an observed increase in the RCP 8.5 scenario is not significant. Similarly, it is important to determine the strategies to be put in place to maintain an adequate level of service over the long term on the one hand and on the other hand to avoid the catchment basins whose concentration time is less than 30 minutes for future development plans for the city of Lomé.

\section{Conclusion:-}

This study has analyzed the impact of climate change on rainfall intensities in the city of Lomé through the development of IDF curves for future climate allowing designers consider future climate differences in sizing optimal sanitation facilities. The results indicate a non-significant difference in rainfall intensities between the current climate and the three future periods considered, whatever the scenario used and the return period. These results, however, demonstrate an upward trend in rainfall intensities using the RCP 8.5 scenario which is in fact related to very high greenhouse gas emissions. This upward trend, even if it is not significant, is a challenge facing the city of Lomé in the optimal management of rainwater. To this end, it is essential to determine to what extent projected increases in precipitation in a future climate may increase the vulnerability of the city of Lome to extreme rainfall events resulting in a decrease in the current level of service, to analyze the measures that can be envisaged to maintain, or at least improve the level of service in a future climate, particularly in the case of already built areas. Certainly, a revision of the design criteria is necessary, but considering the useful life of a great majority of the systems and structures already in place, it is important to consider other measures. Regional climate models to urban catchment scales are needed.

\section{References:-}

1. Adjoussi, P. (2000) Changement climatique global: Evaluation de l'évolution des paramètres climatiques au Togo. Lomé: Université de Lomé FLESH. 
2. Adjoussi P. (2008), Vulnérabilité des systèmes côtiers à l'élévation du niveau marin entre la Volta et le Mono dans le golfe du Bénin (Afrique de l'Ouest). Thèse de doctorat d'Université.

3. Aubréville, A. (1949). Climats, forêts et désertification de l'Afrique tropicale.

4. Benabdesselam, T., \& Hammar, Y. (2009). Estimation de la réponse hydrologique d'un bassin versant urbanisé. European Journal of Scientific Research, 29(3), 334-348.

5. Binguitcha-Fare K. (2003) Analyse des averses au Togo. Nouvelles édition africaines. Lomé

6. Cheikh, M., Ould-Sidi, A., Ozer, P. \& Ozer, A. (2007). Risques d'inondation dans la ville de Nouakchott (Mauritanie). Géo-Eco Trop.

7. Commission Economique des nations unies pour l'Afrique (2015). Rapport d'évaluation sur l'intégration et la mise en œuvre des mesures de réduction des risques de catastrophe au Togo, (76 p). Addis Ababa .

8. Desbordes, M., \& Bouvier, C. (1990). Assainissement pluvial urbain en Afrique de l'ouest. Modélisation du ruissellement. Rapport final, (408p).

9. Direction Générale de l'Hydraulique (2004). Plan Directeur d'Assainissement de la ville de Lomé. Rapport définitif, (286 p).

10. Edjame, K. S. (1992), Changement Climatique global : Les syndromes perçus au Togo. in Actes des journées Scientifiques de l'U.B., Presse De l'U.B. Lomé pp. 169-180.

11. Elgy, J., Maksimovic, C., \& Prodanovic, D. (1993). Matching standard GIS packages with urban storm drainage simulation software. IAHS PUBLICATION, 151-151.

12. Galloway, D. L., \& Burbey, T. J. (2011). Regional land subsidence accompanying groundwater extraction. Hydrogeology Journal, 19(8), 1459-1486.

13. Gbafa, K. S., Tiem, S. \& Kokou, K., (2017a) Characterization of rainwater drainage infrastructure in the city of Lomé (Togo, West Africa). European Scientific-Journal. V 13 n³0: 478-496

14. Gbafa, K. S., Tiem, S. \& Kokou, K., (2017b) Intensity - duration - frequency curves and hydrological response of retention ponds in the city of Lome (Togo, West Africa). Res. J. Engineering Sci.,

15. Huard, D., Mailhot, A., \& Duchesne, S. (2010). Bayesian estimation of intensity-duration-frequency curves and of the return period associated to a given rainfall event. Stochastic Environmental Research and Risk Assessment, 24(3), 337-347.

16. IPCC, 2007. Climate Change 2007: The Physical Science Basis. Summary for Policymakers, Contribution of Working Group I to the Fourth Assessment Report of the Intergovernmental Panel on Climate Change, IPCC Secretariat, Geneva, Switzerland. 103 p

17. Klassou, K.S. (2011). L'urbanisation et l'assainissement pluvial au Togo. Revue de géographie tropicale de l'environnement, (pp. 45-60). Abidjan.

18. Lemmen, D. S., Warren, F. J., Lacroix, J., \& Bush, E. (2008). From impacts to adaptation: Canada in a changing climate. Government of Canada, Ottawa.

19. Mailhot, A., Rivard, G., Duchesne, S. \& Villeneuve, J. P. (2006). Impacts et adaptations liés aux changements climatiques en matière de drainage urbain au Québec. Rapport no. R-874. INRS-ETE. Québec. Canada.

20. Mailhot, A., Duchesne, S., Caya, D., \& Talbot, G. (2007). Assessment of future change in intensity-durationfrequency (IDF) curves for Southern Quebec using the Canadian Regional Climate Model (CRCM). Journal of hydrology, 347(1), 197-210.

21. Mailhot, A., Beauregard, I., Talbot, G., Caya, D., \& Biner, S. (2012). Future changes in intense precipitation over Canada assessed from multi-model NARCCAP ensemble simulations. International journal of climatology, 32(8), 1151-1163.

22. Mailhot, A., Panthou, G., \& Talbot, G. (2014). Recommandations sur les majorations à considérer pour les courbes Intensité-Durée-Fréquence (IDF) aux horizons 2040-2070 et 2070-2100 pour l'ensemble du Québec PHASE II (No. R1515). INRS, Centre Eau Terre Environnement.

23. Min, S. K., Zhang, X., Zwiers, F. W., \& Hegerl, G. C. (2011). Human contribution to more-intense precipitation extremes. Nature, 470(7334), 378-381.

24. Ministère de l'Environnement et des Ressources Forestières (MERF Togo). (2016). Troisième communication nationale du Togo sur les changements climatiques : Etablissement des scénarios climatiques. Rapport définitif, (144 p).

25. Milly, P. C., Betancourt, J., Falkenmark, M., Hirsch, R. M., Kundzewicz, Z. W., Lettenmaier, D. P., \& Stouffer, R. J. (2008). Stationarity is dead: Whither water management? Science, 319(5863), 573-574.

26. Monette, S. A., Velden, C. S., Griffin, K. S., \& Rozoff, C. M. (2012). Examining trends in satellite-detected tropical overshooting tops as a potential predictor of tropical cyclone rapid intensification. Journal of Applied Meteorology and Climatology, 51(11), 1917-1930.

27. Musy, A. N. D. R. É. (2005). Cours" Hydrologie générale". Ecole polytechnique fédérale de Lausanne. 
28. Olsson, J., Berggren, K., Olofsson, M., \& Viklander, M. (2009). Applying climate model precipitation scenarios for urban hydrological assessment: A case study in Kalmar City, Sweden. Atmospheric Research, 92(3), 364375.

29. PANA (2008). Plan d'action national d'adaptation aux changements climatiques. 113 p.

30. Paturel, J. E., Servat, E. \& Delattre, M. O., (1998). Analyse de séries pluviométriques de longue durée en Afrique de l'Ouest et Centrale non sahélienne dans un contexte de variabilité climatique. Journal des Sciences Hydrologiques, 43(6).

31. Sighomnou, D., Tanimoun, B., Alio, A., Zomodo, L., Ilia, A., Olomoda, I., Coulibaly, B., Koné, S., Zinsou, D., \& Dessouassi R. (2012). Crue exceptionnelle et inondation au cours des mois d'août et septembre 2012 dans le Niger moyen et inférieur. ABN (11p). Niamey.

32. Sirastav, R. K., Andre S., \& Slobodan P. S. (2015). Computerized tool for the Development of IntensityDuration-Frequency Curves under a Changing Climate. London, Ontario, Canada, the University of Western Ontario, Department of Civil and Environmental Engineering. v.1.2: 52p.

33. Shaw, S. B., \& Walter, M. T. (2012). Using comparative analysis to teach about the nature of nonstationarity in future flood predictions. Hydrology and Earth System Sciences, 16(5), 1269-1279.

34. Sodogas, A.V. \& Gomado, K. (2006). Analyse situationnelle des risques et facteurs de risques potentiels en matière de désastres au Togo.

35. Sun, L. Y., Aryee, S., \& Law, K. S. (2007). High-performance human resource practices, citizenship behavior, and organizational performance: A relational perspective. Academy of management Journal, 50(3), 558-577.

36. Stocker, T. F., Qin, D., Plattner, G. K., Tignor, M., Allen, S. K., \& Boschung, J. (2013). Cambio Climático 2013: Bases físicas. GTI.: IPCC, 1-5.

37. Wade, s., Faye, S., Dieng, M., Kaba, M., \& Kane, N.R. (2009). Télédétection des catastrophes d'inondation urbaine: Le cas de la région de Dakar (Sénégal). Journal d'Animation Scientifique (7p).

38. Wallez, L. (2010). Inondations dans les villes d'Afrique de l'ouest: diagnostic et éléments de renforcement des capacités d'adaptation dans le Grand Cotonou. Maîtrise en Environnement, Université de Sherbrooke, Sherbrooke.

39. Willems, P. (2000). Compound intensity/duration/frequency-relationship of extreme precipitation for two seasons and two storm types. J hydrol. 233. 189-205.

40. Willems, P., Arnbjerg-Nielsen, K., Olsson, J. \& Nguyen, V.T.V. (2012). Climate changr impact assessment on urban rainfall extremes and urban drainage : Methods and shortcomings. Atmospheric Research. 103 (2012) 106-118. doi:10.1016/j.atmosres.2011.04.003

41. Zwiers, F. W., \& Kharin, V. V. (1998a). Intercomparison of interannual variability and potential predictability: an AMIP diagnostic subproject. Climate dynamics, 14(7), 517-528.

42. Zwiers, F. W., \& Kharin, V. V. (1998b). Changes in the extremes of the climate simulated by CCC GCM2 under CO2 doubling. Journal of Climate, 11(9), 2200-2222. 